\title{
EASI - European Autoimmunity Standardisation Initiative: facing the challenges of diagnostics in autoimmunity
}

Citation for published version (APA):

Damoiseaux, J., Olschowka, N., \& Shoenfeld, Y. (2018). EASI - European Autoimmunity Standardisation Initiative: facing the challenges of diagnostics in autoimmunity. Clinical Chemistry and Laboratory Medicine, 56(10), 1620-1623. [10]. https://doi.org/10.1515/cclm-2017-0826

Document status and date:

Published: 01/10/2018

DOI:

10.1515/cclm-2017-0826

Document Version:

Publisher's PDF, also known as Version of record

\section{Document license:}

Taverne

Please check the document version of this publication:

- A submitted manuscript is the version of the article upon submission and before peer-review. There can be important differences between the submitted version and the official published version of record.

People interested in the research are advised to contact the author for the final version of the publication, or visit the DOI to the publisher's website.

- The final author version and the galley proof are versions of the publication after peer review.

- The final published version features the final layout of the paper including the volume, issue and page numbers.

Link to publication

\footnotetext{
General rights rights.

- You may freely distribute the URL identifying the publication in the public portal. please follow below link for the End User Agreement:

www.umlib.nl/taverne-license

Take down policy

If you believe that this document breaches copyright please contact us at:

repository@maastrichtuniversity.nl

providing details and we will investigate your claim.
}

Copyright and moral rights for the publications made accessible in the public portal are retained by the authors and/or other copyright owners and it is a condition of accessing publications that users recognise and abide by the legal requirements associated with these

- Users may download and print one copy of any publication from the public portal for the purpose of private study or research.

- You may not further distribute the material or use it for any profit-making activity or commercial gain

If the publication is distributed under the terms of Article $25 \mathrm{fa}$ of the Dutch Copyright Act, indicated by the "Taverne" license above, 


\section{Mini Review}

Jan Damoiseaux*, Nina Olschowka and Yehuda Shoenfeld

\section{EASI - European Autoimmunity Standardisation Initiative: facing the challenges of diagnostics in autoimmunity}

https://doi.org/10.1515/cclm-2017-0826

Received September 12, 2017; accepted October 24, 2017; previously published online November 25, 2017

\begin{abstract}
The European Autoimmunity Standardisation Initiative (EASI) has been founded in order to improve autoimmune diagnostics by stimulating the interaction between the clinicians and laboratory specialists, by standardization of autoantibody tests, and by harmonization of testing algorithms. The ultimate goal of EASI is to utilize autoimmune diagnostics in the best way in order to optimize patient care. This mini-review gives an overview of the historical perspective of EASI and summarizes the major achievements.
\end{abstract}

Keywords: autoantibody; communication; harmonization; standardization.

\section{Introduction}

Autoimmunity - the reaction of the immune system against its own body - is known to be the pathogenic cause of more than 80 diseases [1, 2] and probably many more diseases would be included in this group if their pathogenesis was known in more detail. Autoimmune diseases are a very heterogeneous group ranging from organ-specific disorders such as diabetes mellitus type 1 to systemic diseases where almost all parts of the body might be involved such as systemic lupus erythematosus. Specialists of nearly all medical areas may face clinical manifestations related to autoimmune diseases - from the

*Corresponding author: Jan Damoiseaux, PhD, Central Diagnostic Laboratory, Maastricht University Medical Center, P. Debyelaan 25, $6229 \mathrm{HX}$ Maastricht, The Netherlands,

E-mail: jan.damoiseaux@mumc.nl

Nina Olschowka: Phadia GmbH, Thermo Fisher Diagnostics, Freiburg, Germany

Yehuda Shoenfeld: Zabludowicz Center for Autoimmune Diseases, Sheba Medical Center (Affiliated to Tel-Aviv University), Tel-Hashomer, Israel general practitioner to the pediatrician, the gynecologist or even dentist. Every clinician has heard of autoimmune diseases during their studies but in the reality of routine working life, very few doctors would call themselves autoimmunologists [3-5]. The fact that autoimmune diseases have such a broad range of clinical presentations, and that, in particular, the rare systemic autoimmune diseases are extremely hard to diagnose, leads to a lack of confidence in the majority of clinicians. If autoimmunity is a possible explanation for the symptoms of a patient, many doctors order tests for a broad number of markers, in particular autoantibodies [1, 2], hoping for any hint, which might assist in the diagnosis. The correct interpretation of the laboratory findings, however, needs knowledge and experience which most non-specialized clinicians do not have. The consequences are manifold: long delays between first symptoms and diagnosis, lengthy, stressful and ultimately unnecessary waiting times for centers specialized in autoimmune diseases, underestimation of lesser known diseases, misdiagnoses and, alas, even incorrect and possibly harmful treatment.

\section{EASI: from idea to organization}

The non-profit organization "European Autoimmunity Standardisation Initiative" EASI was established with the goal of improving the situation in autoimmunity diagnostics, mostly by education of clinicians and laboratory staff and by improving the communication between the laboratory and clinicians [6]. "Autoimmunity Standardization" refers in this case to standardized routine procedures in laboratories and a more standardized communication, e.g. by recommendations regarding which information should always be added to an antibody result to facilitate the interpretation by the clinician. EASI focusses majorly on rheumatic/systemic autoimmune diseases as the diagnostic situation is particularly complex in this area.

The idea of EASI was first raised by the Danish autoimmunity specialist Dr. Alan Wiik in 2002 in a discussion 


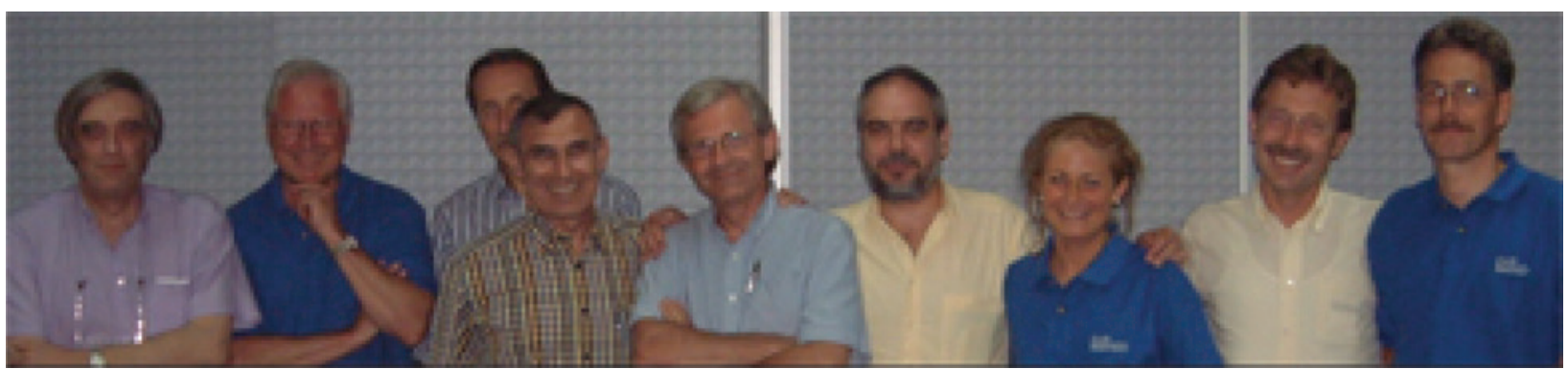

Figure 1: Founders of EASI.

Apart from Alan Wiik who was also the president of the group in the early years (second from left), founding members were from left to right Jean-Charles Piette (France), Pier-Luigi Meroni (Italy), Yehuda Shoenfeld (Israel), Cees Kallenberg (The Netherlands), Munther Khamashta (Great Britain), Alison Sunset (Norway, representative of Phadia), Reinhold E. Schmidt (Germany), and Michael Haass (Germany, representative of Phadia). (Unfortunately this poor quality photograph is the only one available of the founding group.)

with members of the diagnostic company Phadia, nowadays a Thermo Fisher Scientific company [7]. The founders of EASI are depicted in Figure 1. Right from the beginning the group agreed that Phadia would neither intervene nor have any influence on the content discussed at EASI, but would act purely as a facilitator: organizing the meetings and keeping the group "alive". As part of the agreement, no other commercial company would be allowed to participate in EASI. Since 2006, Yehuda Shoenfeld has been the president and speaker of the EASI Forum Group.

EASI operates on two levels - the local EASI groups, each restricted to a single European country (Figure 2), and the international forum group, which consists of representatives from these local groups. All EASI groups aim to include both laboratory and clinical autoimmunity specialists. In several countries the EASI groups have

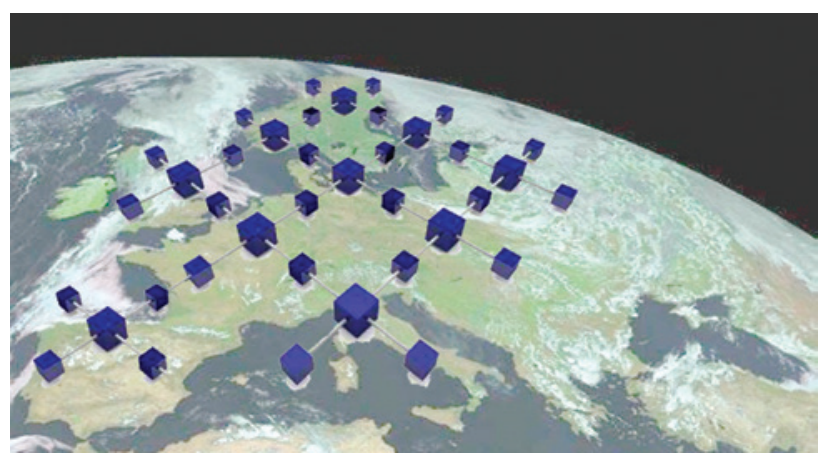

Figure 2: Participating countries.

Today, local EASI groups exist in 15 different countries (in alphabetical order): Austria, Belgium, Estonia/Baltic countries, Finland, France, Germany, Israel, Italy (presented by the group F.I.R.M.A.), the Netherlands, Norway, Portugal, Russia, Spain, Sweden and Ukraine. Additionally, a Swiss group of laboratory and clinical autoimmunity specialists is closely linked to EASI and sends representatives to the international EASI Forum Group meetings. arisen from or have integrated with pre-existing networks of autoimmunologists.

While each local group may have its own activities adapted to the special needs of its country, the EASI Forum Group meets at least once a year to share experiences and to coordinate activities within Europe.

\section{Achievements}

One success from the international collaboration is the book The General Practice Guide to Autoimmune Diseases which covers the whole spectrum of autoimmune diseases [8]. For each disease characteristic clinical manifestation are enlisted and diagnostic strategies, including details on the relevant laboratory tests, are described. This was published in 2012 and has been translated into German and recently also into Russian.

From the first meetings of EASI, the group discussed how to evaluate the way in which laboratories in Europe handle autoimmune markers, in particular autoantibodies, in their routine practice. The first group survey carried out in most countries where EASI groups existed was on ANA/ENA test algorithms. The results revealed that harmonization was limited not only between, but also within the participating countries [9]. On the basis of the results of this survey, EASI developed recommendations for ANA/ENA testing in collaboration with the International Union of Immunological Societies (IUIS) [10]. Whether these recommendations have resulted in better alignment of testing algorithms remains to be determined. With a very similar approach, EASI carried out a European-wide survey on ANCA test algorithms [11]. From this survey it was learned that diagnostic laboratories adhered poorly to the 1999 international consensus on ANCA testing [12] 
and that there is an urgent need for an update of this consensus. This update has recently come available, independently from EASI, as based on a EUVAS multicenter study on ANCA testing in ANCA-associated vasculitis $[13,14]$.

It is evident that active participation of the local EASI groups was detrimental in the achievements mentioned above. In several countries the national results of the surveys have been analyzed in more detail in order to further harmonize autoimmune diagnostics in the respective country [15-18]. Also, the issued recommendations and consensus may help the EASI groups to change reimbursement policies in their country. As mentioned, the local EASI groups have their own initiatives which primarily focus on increasing the awareness of autoimmune diseases and related diagnostics on a national level by preparing educational documents and/or organizing dedicated courses.

Members of EASI have strong networks in the autoimmunity community which allows EASI to have productive collaborations with other initiatives and organizations such as IUIS, EULAR, EUVAS, or the European Forum on Antiphospholipid Antibodies [19]. Additionally, EASI plays an active role in supporting both the European Initiative for Harmonizing AI Tests which has developed new reference material for MPO and PR3 ANCAs [20], as well as the International Consensus on ANA Patterns (ICAP) [21]. Finally, EASI has taken the challenge to facilitate accreditation of autoimmune diagnostic laboratories by defining the organizational model and the resources and expertise required for a clinical laboratory specialized in autoimmune diagnostics [22].

\section{Conclusions}

Globally, autoimmunity patients rely on the skill and knowledge of their clinician. EASI offers a way for autoimmunity specialists to work together to improve and communicate the information about the disorders and, ultimately, to improve the lives of these patients.

Author contributions: All the authors have accepted responsibility for the entire content of this submitted manuscript and approved submission.

Research funding: None declared.

Employment or leadership: None declared.

Honorarium: None declared.

Competing interests: The funding organization(s) played no role in the study design; in the collection, analysis, and interpretation of data; in the writing of the report; or in the decision to submit the report for publication.

\section{References}

1. Shoenfeld Y, Meroni PL, Gerswin ME, editors. Autoantibodies, 3rd ed. Oxford: Elsevier, 2013.

2. Shoenfeld Y, Cervera R, Gerswin ME, editors. Diagnostic criteria in Autoimmune diseases, 1st ed. Totowa, NJ: Humana Press, 2008.

3. Tozzoli R, Bizzaro N. The clinical autoimmunologist and the laboratory autoimmunologist: the two sides of the coin. Autoimmun Rev 2012;11:766-70.

4. Matthias T, Shoenfeld Y. Challenges for the autoimmunologist. Clin Rev Allergy Immunol 2010;38:75-6.

5. Anaya JM, Shoenfeld Y, Cervera R. Facts and challenges for the autoimmunologists. Lessons from the second Colombian autoimmune symposium. Autoimmun Rev 2012;11:249-51.

6. Shoenfeld Y, Cervera R, Haass M, Kallenberg C, Khamashta $M$, Meroni P, et al. EASI - the European Autoimmunity Standardisation Initiative: a new initiative that can contribute to agreed diagnostic models of diagnosing autoimmune disorders throughout Europe. Ann NY Acad Sci 2007;1109:138-44.

7. Wiik A, Cervera R, Haass M, Kallenberg C, Khamashta M, Meroni $\mathrm{PL}$, et al. European attempts to set guidelines for improving diagnostics of autoimmune rheumatic disorders. Lupus 2006;15:391-6.

8. Shoenfeld Y, Meroni PL, editors. The general practice guide to autoimmune diseases. Lengerich: Pabst Science Publisher, 2012.

9. Damoiseaux J, Agmon Levin N, Van Blerk M, Chopyak V, Eriksson C, Heijnen I, et al. From ANA-screening to antigen-specificity: an EASI-survey on the daily practice in European countries. Clin Exp Rheumatol 2014;32:539-46.

10. Agmon-Levin N, Damoiseaux J, Kallenberg C, Sack U, Witte T, Herold M, et al. International recommendations for the assessment of autoantibodies helped to cellular antigens referred to as anti-nuclear antibodies. Ann Rheum Dis 2014;73:17-23.

11. Damoiseaux J, Heijnen I, Van Campenhout C, Eriksson C, Fabien $\mathrm{N}$, Herold $\mathrm{M}$, et al. An international survey on anti-neutrophil cytoplasmic antibodies (ANCA) testing in daily clinical practice. Clin Chem Lab Med 2018;56:1759-70.

12. Savige J, Gillis D, Benson E, Davies D, Esnault V, Falk RJ, et al. International consensus statement on testing and reporting of antineutrophil cytoplasmic antibodies (ANCA). Am J Clin Pathol 1999;111:507-13.

13. Damoiseaux J, Csernok E, Rasmussen N, Moosig F, van Paassen $P$, Baslund B, et al. Detection of antineutrophil cytoplasmic antibodies (ANCAs): a multicentre European Vasculitis Study Group (EUVAS) evaluation of the value of indirect immunofluorescence (IIF) versus antigen-specific immunoassays. Ann Rheum Dis 2017;76:647-53.

14. Bossuyt X, Cohen Tervaert JW, Arimura Y, Blockmans D, Flores-Suárez LF, Guillevin L, et al. Revised 2017 international consensus on testing of ANCA in granulomatosis with polyangiitis and microscopic polyangiitis. Nat Rev Rheumatol 2017;13:683-92.

15. Sack U, Conrad K, Csernok E, Frank I, Hiepe F, Krieger T, et al. Autoantibody detection using indirect immunofluorescence on HEp-2 cells. Ann NY Acad Sci 2009;1173:166-73.

16. Damoiseaux J, Bakker-Jonges L, Cohen Tervaert JW, Derksen R, Hooijkaas H, Kallenberg C, et al. Laboratoriumdiagnostiek van 
ANA, anti-ds-DNA- en anti-ENA-antistoffen: aanbevelingen naar aanleiding van een enquête. Ned Tijdschr Klin Chem Labgeneesk 2010;35;234-9.

17. Van Blerk M, Bossuyt X, Humbel R, Mewis A, Servais G, Tomasi JP, et al. Belgian recommendations on ANA, anti-dsDNA and anti-ENA antibody testing. Acta Clin Belg 2014;69:83-6.

18. Herold M, Klotz W, Demel U, Endler G, Forster E, Griesmacher $A$, et al. International consensus on ANA determination - what changes in the German-speaking area? J Lab Med 2015;39:145-52.

19. Damoiseaux J, Andrade LE, Fritzler MJ, Shoenfeld Y. Autoantibodies 2015: from diagnostic biomarkers toward prediction, prognosis and prevention. Autoimmun Rev 2015;14:555-63.
20. Monogioudi E, Hutu DP, Martos G, Sheldon J, Schimmel H, Meroni PL, et al. Development of a certified reference material for myeloperoxidase-anti-neutrophil cytoplasmic autoantibodies (MPO-ANCA). Clin Chim Acta 2017;467:48-50.

21. Chan EK, Damoiseaux J, Carballo OG, Conrad K, de Melo Cruvinel W, Francescantonio PL, et al. Report of the first international consensus on standardized nomenclature of antinuclear antibody HEp-2 cell patterns 2014-2015. Front Immunol 2015;6:1-13.

22. Bizzaro N, Bossuyt X, Haapala AM, Shoenfeld Y, Sack U. Accreditation in autoimmune diagnostic laboratories. A position paper of the European Autoimmunity Standardisation Initiative (EASI). Autoimmun Rev 2017;16:81-6. 